\title{
Oral verruciform xanthoma: Report of 13 new cases and review of the literature
}

\author{
Paris Tamiolakis ${ }^{1}$, Vasileios I. Theofilou ${ }^{1}$, Konstantinos I. Tosios ${ }^{2}$, Alexandra Sklavounou-Andrikopoulou ${ }^{3}$ \\ ${ }^{1}$ DDS, Postgraduate Student, Department of Oral Medicine and Oral Pathology, School of Dentistry, National and Kapodistrian \\ University of Athens, Greece, 2 Thivon Str, 11527 Athens, Greece \\ ${ }^{2}$ DDS, PhD, Assistant Professor, Department of Oral Medicine and Oral Pathology, School of Dentistry, National and Kapodis- \\ trian University of Athens, Greece, 2 Thivon Str, 11527 Athens, Greece \\ ${ }^{3}$ DDS, MSc, PhD, Professor, Head of Department of Oral Medicine and Oral Pathology, School of Dentistry, National and Ka- \\ podistrian University of Athens, Greece, 2 Thivon Str, 11527 Athens, Greece
}

Correspondence:

Department of Oral Medicine and Oral Pathology

School of Dentistry

National and Kapodistrian University of Athens

Greece, 2 Thivon Str, 11527, Goudi, Athens, Greece

ptamiolakis@hotmail.com

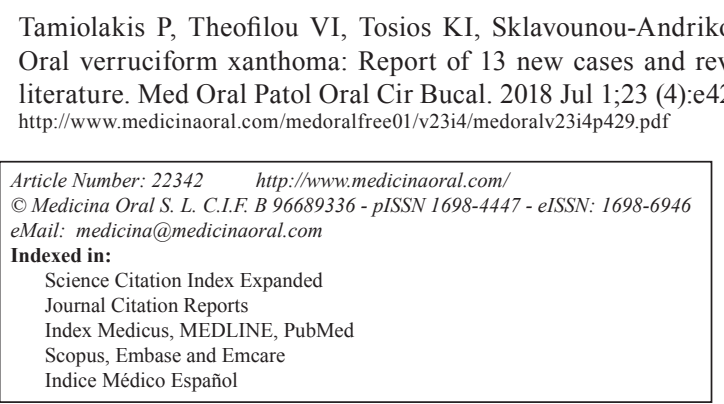

\begin{abstract}
Background: Oral verruciform xanthoma (OVX) is a rare lesion. The purpose of the present study is to describe the clinical features of 13 OVXs and review all cases reported in the English literature.

Material and Methods: Thirteen cases of OVX diagnosed during a 47-year period were retrospectively collected. The patients' gender and age, as well as the main clinical features of the lesions were retrieved from the biopsy request forms. Pubmed ${ }^{\circledR}$, Scopus ${ }^{\circledR}$ and Google Scholar ${ }^{\mathrm{TM}}$ electronic databases were searched with the key word "verruciform xanthoma". Only cases of histologically confirmed OVX were included in the study.

Results: The 13 OVXs represented approximately $0.04 \%$ of 35,617 biopsies accessioned during the study period. They affected 13 patients, 8 males and 5 females with a mean age of $48.8 \pm 14$ years. They mainly appeared as asymptomatic granular nodules or plaques, with elastic or normal consistency and white color, in the gingiva or hard palate. Literature review yielded 416 cases of OVX. With the addition of cases of the present study, 429 cases of OVX have been presented in the English literature. OVX has a slight male predominance with a male to female ratio of 1.4:1 and the majority of patients are in the 5th to 7th decade of life. Clinically, OVX mainly presents as an asymptomatic, single, papillary or granular plaque or nodule, with elastic or soft consistency and white, red or pink color. It measures approximately $1 \mathrm{~cm}$ and is most commonly located on the gingiva, tongue, hard palate or buccal mucosa. The treatment of choice is surgical excision with little rates of recurrence.

Conclusions: Verruciform xanthoma is a rare lesion most often encountered on the ginigival mucosa. As its clinical presentation is not pathognomonic, it should be included in the differential diagnosis of verrucous or papillary lesions.
\end{abstract}

Key words: Oral verruciform xanthoma, oral tumors. 


\section{Introduction}

Verrucifrom xanthoma is a rare benign lesion of unknown pathogenesis, first described in the oral cavity by Shafer in 1971 (1). Similar lesions have been reported in the anogenital area (2), i.e. the penis, the scrotum and vulva (3), as well as in the skin, the latter usually in association with chronic inflammatory skin diseases such as dystrophic epidermolysis bullosa and cutaneous discoid lupus erythematous, chronic or congenital lymphoedema, graft versus host disease, and congenital epidermal nevi (2).

Oral verruciform xanthoma (OVX) manifests as an asymptomatic, solitary, sharply demarcated and slightly raised plaque usually located on the gingiva, with a papillary, granular or verrucous surface, and red or pink color (4). It shows a slight male predilection and most patients are in the 5th to 7th decade of life (4). Microscopic examination discloses a papillary or verrucous proliferation of hyperparakeratotic squamous epithelium with a characteristic orange hue, and aggregation of "foamy or xanthoma cells" within the connective tissue (4-6). The ret pegs are elongated with uniform depth $(4,7)$ and deep, keratin-filled clefts may be noticed between the epithelial projections (4). Exocytosis of neutrophils in the parakeratin layer and infiltration of lymphocytes and plasma cells in the connective tissue may also be seen (7). The xanthoma cells are macrophages of varying size with eccentrically placed nuclei $(4,8)$; they are mostly confined to the connective tissue papillae, but may extend beyond the level of the rete ridges $(7,8)$. They may replace all connective tissue elements in the papillae or be sparsely present $(4,7)$.

We report the clinical features of 13 new cases of OVX and review the pertinent English literature with regard to the clinical and demographic features, etiology, pathogenesis and treatment.

\section{Material and Methods}

The study was approved by the Research Ethics Committee of Athens Dental School (code number 349/08.11.2017).

Fourteen cases of OVX were retrospectively retrieved from the files of the Department of Oral Medicine and Pathology from January 1971 to July 2017. The diagnosis in each case was reconfirmed by studying representative hematoxylin and eosin stained tissue sections. The age and gender of the patients, as well as location and main clinical features of the lesions were collected from the biopsy request forms and tabulated.

For the literature review, Pubmed $\AA$, Scopus $\AA$ and Google Scholar ${ }^{\mathrm{TM}}$ electronic databases were searched using the keyword "verruciform xanthoma" up to July 15, 2017. All cases of microscopically confirmed VX located in the oral mucosa that were published in the English literature were retrieved. The references of all retrieved publications were manually searched for additional cases. Multiple lesions or recurrences were considered as OVX only when they were microscopically confirmed. The age and gender of the patients, location and main clinical features of the lesions, as well as follow-up data were collected and tabulated.

\section{Results}

Out of 35,617 biopsies accessioned during the study period, 14 cases of solitary OVX were found, representing $0.04 \%$ of total number. As one of those cases had been previously described in the English literature (9), the clinical features of the 13 new cases are tabulated in Table 1. Eight patients $(61.5 \%)$ were males and $5(38.5 \%)$ were females, the male to female ratio being 1.6:1. Age was reported in eleven patients and ranged from 28 to 73 years (mean age $48.8 \pm 14$ years, median age 48 years). The mean age of the males (mean age $42.1 \pm 11.6$ years, median 38 years) was younger than that of the females (mean age $60.5 \pm 9.4$ years, median 60.5 years), the difference being statistically significant $(p<0.05)$. Most lesions were clinically described as asymptomatic nodules ( 6 cases, $46.2 \%$ ), plaques ( 5 cases, $38.5 \%$ ) or ulcers ( 2 cases, $15.4 \%$ ), of white ( 8 cases, $72.7 \%$ ), pink ( 2 cases, $18.2 \%$ ), or red (1 case, 9.1\%) color. Their surface was granular (6 cases, $54.5 \%$ ), rough ( 2 cases, $18.2 \%$ ), papillary ( 2 cases, $18.2 \%$ ) or verrucous ( 1 case, $9.1 \%$ ). Consistency was described as elastic (5 cases, $62.5 \%$ ), normal ( 2 cases, $25 \%$ ) or soft (1 case, $12.5 \%$ ). Size was reported in 9 cases and approximately half of them measured less than $1 \mathrm{~cm}$ in largest dimension (range $0.3-2.5 \mathrm{~cm}$, mean $1 \pm 0.7 \mathrm{~cm}$, median $0.7 \mathrm{~cm})$. Most lesions were located on the gingiva ( 5 cases, $38.5 \%$ ), followed by the hard palate ( 3 cases, $23.1 \%$ ), lateral border of the tongue ( 2 cases, $15.4 \%)$, lower lip ( 2 cases, $15.4 \%$ ) and alveolar mucosa (1 case, $7.7 \%$ ).

The literature review yielded 74 publication with a total number of 416 cases of OVX $(1,4,9-73)$. With the addition of the 13 new cases of the present study, the total number of OVXs reported in the English literature is 429. There was a slight male predominance with 233 cases (58\%) occurring in male patients and 169 cases (42\%) in females (male to female ratio 1.4:1). Age ranged from 2.5 to 89 years, with the majority of patients being in the 5th to 7 th decade of life (mean age 51 years). The mean age of males (47.6 years) was younger than that of females (55.8 years), the difference being statistically significant $(p<0.05)$. Male to female ratio before the age of 50 years was 2.1:1, but after the age of 50 years is approximately $1: 1$. Age distribution according to gender is shown in Fig 1. OVX usually manifested as a single lesion (341 cases, $98.6 \%)$, but in 5 cases $(4,24,42,55,71)$ multiple lesions were seen. There were, also, 2 cases with multiple lesions $(39,72)$, but biopsy was performed in only one of them. In one case (55) 4 OVXs were 
Table 1: Demographics and clinical characteristics of 13 cases of oral verruciform xanthoma.

\begin{tabular}{|l|c|c|c|c|c|c|c|c|c|c|}
\hline Case & Gender & Age* & Site & Size** & Clinical & Consistency & Surface & Color & Duration & Symptoms \\
No. & & & & & & & & & \\
\hline 1 & M & 36 & MaAG & 0.5 & Nodule & Elastic & Granular & Pink & 36 & No \\
\hline 2 & M & 38 & MxPG & 1.5 & Ulcer & - & Papillary & White & 0,5 & - \\
\hline 3 & M & 36 & MaPG & 0.3 & Nodule & Elastic & Rough & White & 12 & No \\
\hline 4 & F & - & LLM & 0.7 & Nodule & Elastic & Granular & White & 12 & No \\
\hline 5 & M & - & LLM & 1 & Nodule & Elastic & Granular & White & - & No \\
\hline 6 & M & 63 & MxAM & 0.5 & Nodule & Soft & Granular & - & - & No \\
\hline 7 & F & 48 & HP & - & Plaque & - & - & - & No \\
\hline 8 & F & 56 & LT & - & Nodule & Elastic & Veruccous & Pink & 3 & - \\
\hline 9 & M & 28 & MxPG & 1.5 & Ulcer & - & Rough & White & 2 & No \\
\hline 10 & F & 65 & HP & - & Plaque & Normal & - & White & 12 & No \\
\hline 11 & M & 38 & MxAG & - & Plaque & - & Granular & White & 0,5 & No \\
\hline 12 & F & 73 & HP & 0.5 & Plaque & Normal & Granular & Red & 0,75 & No \\
\hline 13 & M & 56 & LT & 2.5 & Plaque & - & Papillary & White & - & No \\
\hline
\end{tabular}

*Years, ${ }^{* *}$ Maximum diameter in $\mathrm{cm},{ }^{* * *}$ Months.

Abbreviations: M, male; F, female; MaAG, mandibular anterior gingiva; MxAG, maxillary anterior gingiva; MxPG, maxillary posterior gingiva; MaPG, mandibular posterior gingiva; LLM, lower lip mucosa; MxAM, maxillary alveolar mucosa; HP, hard palate; LT, lateral tongue.

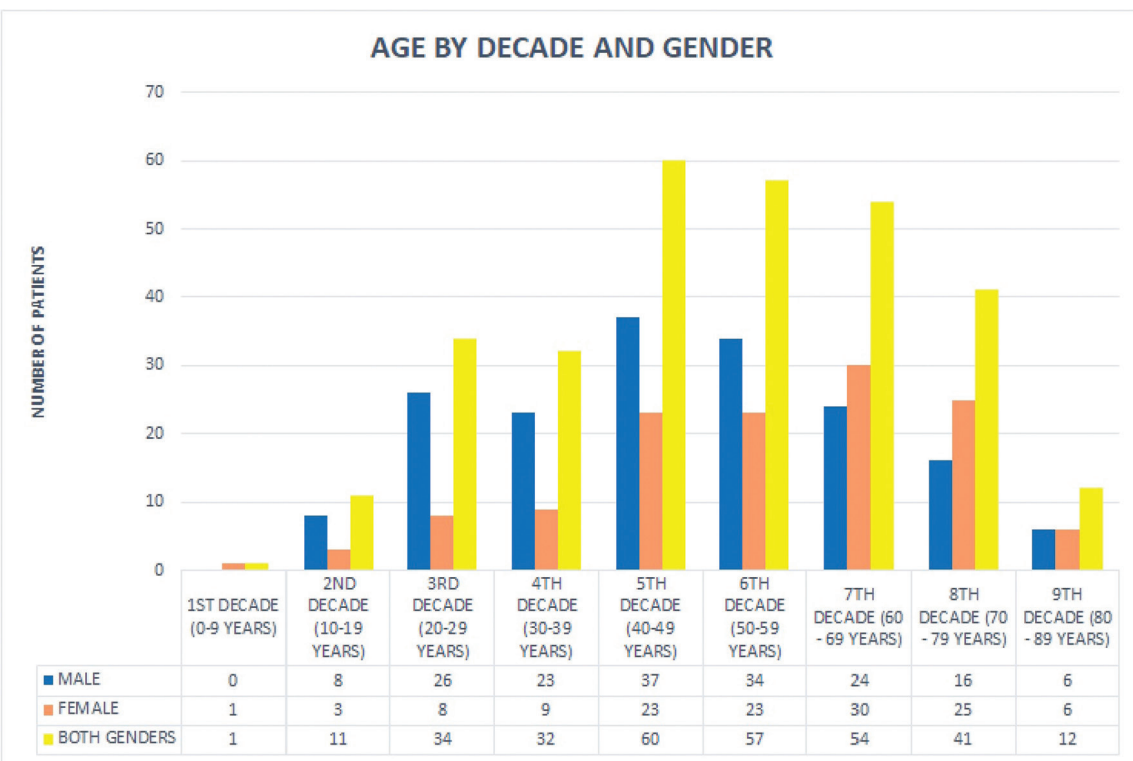

Fig. 1: Age of patients related to gender and decade of life.

present and in another 4 cases 2 lesions were detected $(4,24,42,71)$. In 2 cases, OVX manifested concurrently with extraoral lesions $(25,66)$, while one case with multifocal lesions was described as "disseminated" verru- cifom xanthoma (74). The majority of OVXs were located on the gingiva (182 cases, $45.3 \%$ ), followed by the tongue (53 cases, $13.2 \%$ ), hard palate (51 cases, $12.7 \%$ ), buccal mucosa (37 cases, 9.2\%), alveolar mucosa (25 
cases, $6.2 \%$ ), floor of the mouth (15 cases, 3.7\%), lips (15 cases, 3.7\%), soft palate ( 9 cases, $2.2 \%$ ), maxillary buccal vestibule (4 cases, $1 \%$ ), vermillion border of the lower lip ( 3 cases, $0.7 \%$ ), palatal junction ( 3 cases, $0.7 \%$ ) and lower mucobuccal fold ( 2 cases, $0.5 \%$ ). Single cases were also seen on the retromolar pad $(0.3 \%)$, mandibular posterior gingiva with extension to the buccal mucosa $(0.3 \%)$ and maxillary anterior gingiva extending to the upper lip (0.3\%). Clinically, in the majority of cases, OVX presented as a plaque (19 cases, 38\%), nodule (11 cases, $22 \%$ ) or mass ( 6 cases, $12 \%$ ), of white (22 cases, 29\%), red (15 cases, 19.7\%), pink (14 cases, $18.4 \%$ ) or yellow (10 cases, $13.2 \%$ ) color, with elastic ( 6 cases, $40 \%$ ) or soft ( 6 cases, $40 \%$ ), consistency. The surface was papillary (35 cases, $38.5 \%$ ), granular (22 cases, $24.2 \%$ ), or verrucous (17 cases, 18.7\%). Most lesions measured approximately $1 \mathrm{~cm}$ in major diameter (mean size $1 \pm 0.7 \mathrm{~cm}$, median size $1 \mathrm{~cm}$ ). In $95.7 \%$ of the cases no symptoms were present, justifying the long duration of $12.8 \pm 19.7$ months (range 2 weeks- 12 years, median duration 6 months) before diagnosis. In one case (11) a barely discernible radiolucency could be noticed upon radiographic examination. The follow up period ranged from 2 months - 18 years (mean follow-up time $8.9 \pm 8$ years, median follow-up time 3 years) and 6 cases recurred (12\%). In $99.1 \%$ of the cases, surgical excision was performed, whereas in 2 cases diagnosis was established after incisional biopsy followed by total excision with electro-cautery knife (28) or carbon dioxide laser (49). In one case (66) imiquimod was locally applied after surgical excision.

Cases of OVX was described in patients with oral lichen planus (10 cases) $(7,15,16,32,35,41,48,65)$; graft versus host disease ( 7 cases) $(4,29,46)$; bone marrow transplantation (5 cases) $(49,53,66$, cases 4 and 5 of the present study); oral squamous cell carcinoma (4 cases) $(15,26,41,65)$; leukoplakia (1 case) (7); amyloidosis (1 case) (7); in patients under chemotherapy and radiotherapy for lymphoma (2 cases) (8); oral pemphigus vulgaris (1 case) (19), oral discoid lupus erythematous (1 case) (37), submucosal fibrosis (1 case) (41), neurofibromatosis ( 1 case) (47) and paracoccioidiomycosis (1 case) (65). In three cases, OVX occurred simultaneously with osteoma (8), carcinoma in situ (26) and warthy dyskeratoma (30).

\section{Discussion}

OVX is a rare lesion, as Shafer (1) reported 15 cases $(0,045 \%)$ among 33,000 biopsies during a 23 year period and Jones and Franklin (75) 9 cases (0.02\%) among 44,007 biopsies during a 30 year period. The 14 cases retrieved from the files of our Department represent $0.04 \%$ of 35.617 biopsies diagnosed during a 47 year period. In their review Philipsen et al. (4) found 199 cases of OVX in the English literature and 83 cases in the Jap- anese literature. Since this review 134 cases have been published in the English literature that in addition to the 13 new cases found in our files raise the total number of OVX to 429 cases. The more common occurrence of OVX in males than females and in middle-aged patients (4) was confirmed in the present study. The clear male predominance of the lesion in patients younger than 50 years of age, as well as their tendency to occur almost a decade earlier in males compared to females cannot be explained. The gingiva is the most commonly involved oral site, followed by the tongue, hard palate, and buccal mucosa (4).

The clinical differential diagnosis includes other verrucous lesions, such as verrucous leukoplakia, verrucous carcinoma, squamous papilloma, verruca vulgaris, condyloma acuminatum and squamous cell carcinoma $(46,63)$.

Diagnosis requires microscopic examination. Nowparast et al. (17) have described three histologic subtypes of OVX that do not correlate with clinical or prognostic parameters, and most probably represent various stages of the disease progression (25).

Immunohistochemically, parakeratin is negative for cytokeratin (CK) 14, in contrast to normal oral epithelium and Syndecan 1/CD138 shows granular positivity compared to normal oral mucosa, where a membranous pattern is seen (65). The foam cells are positive for CD68 and negative for S-100, positive for PAS and PAS-diastase $(6,8)$ and some of them may represent transformed fibroblasts (7).

The pathogenesis of OVX is unknown. Unlike skin xanthomas no disturbance of lipid metabolism is reported, with the exception of one case (25) in a girl with an undefined systemic lipid disorder who developed a verruciform xanthoma on the tongue and in other parts of her body. A missense mutation in exon 6 of the $3 \beta$-hydroxysteroid dehydrogenase (NSDHL) gene that plays an important role in cholesterol biosynthesis was found in $22 \%$ of cutaneous xanthomas, but this mutation has not been examined in OVX (76). As in cutaneous lesions (2), OVX is not related to HPV $(25,33,38)$. Occurrence of most OVX on the masticatory mucosa lead to the hypothesis that a "local irritant", such as trauma or inflammation, may cause epithelial degeneration and that the degenerated epithelium forms lipids scavenged by macrophages $(12,13)$. However, this theory does not explain the occurrence of OVX in sites where trauma is not common, such as the soft palate or floor of the mouth (4), the lack of degenerative epithelial cells on microscopic examination $(8,9)$ and the persistence of foamy cells in the connective tissue (5). Some authors consider the epithelial changes as secondary to the presence of foamy cells $(17,25)$ or "illusionary" (8) due to the upward pushing effect from the macrophages.

Accumulation of $\mathrm{T}$ lymphocytes, decreased number of 
Langerhans cells (8) and active antigen presentation in the epithelium of OVX, especially at the site of intense inflammation (33), suggest a local immunologic reaction (5). Accumulation of an inflammatory infiltrate predominated by $\mathrm{T}$ lymphocytes to an unknown antigen may act as a chemoattractant to macrophages that through the expression of epithelial adhesion molecules persist in the lesion (5). According to Ide et al. (7), periodontopathic pathogens, tobacco, mechanical stimuli, alcohol, foodstuff sensitizing or allergic agents or dental materials and drugs, alter keratinocytes causing chronic epithelial damage and trigger inflammation, with the predominance of $\mathrm{T}$ lymphocytes. T lymphocytes in turn stimulate keratinocytes to release cytokines and chemokines, thus attracting neutrophils (by IL-8 of the upper spinous keratinocytes) and additional $\mathrm{T}$ cells thus perpetuating $\mathrm{T}$ cell infiltration. $\mathrm{T}$ lymphocytes activate MCP-1 in the basal layer cells, which is a monocyte/macrophage cells attractor, thus attracting macrophages that express CCR2, the receptor of MCP1. Macrophages trap and internalize lipids released by degenerative keratinocytes, thus becoming foamy. Consequently, macrophages oxidize lipids causing self induced-toxicity and eventually necrosis. The inflammatory response to necrosis attracts new macrophages, thus perpetuating their presence in OVX (7). Finally Shahrabi Farahani et al. (46) proposed that disorders which lead to basal cells damage such as lichen planus, GVHD, pemphigus vulgaris and epidermolysis bullosa may also trigger the formation of OVX.

OVX has good prognosis. Only 6 cases with recurrence after surgical excision (12\%) (mean time of recurrence $2.8 \pm 1.5$ years) were recorded $(17,22,33,7,47,57)$. This underlines the necessity for a follow-up. No case of malignant transformation has been reported. In one case squamous cell carcinoma developed in the area where an OVX was present four years earlier, but this was considered coincidental (6).

\section{Conclusions}

Verruciform xanthoma is a rare lesion most often encountered on the ginigival mucosa. As its clinical presentation is not pathognomonic, it should be included in the differential diagnosis of verrucous or papillary lesions.

\section{References}

1. Shafer WG. Verruciform xanthoma. Oral Surg Oral Med Oral Pathol. 1971;31:784-9.

2. Blankenship DW, Zech L, Mirzabeigi M, Venna S. Verruciform xanthoma of the upper-extremity in the absence of chronic skin disease or syndrome: a case report and review of the literature. J Cutan Pathol. 2013;40:745-52.

3. Stiff KM, Cohen PR. Vegas (Verruciform Genital-Associated) Xanthoma: A Comprehensive Literature Review. Dermatol Ther (Heidelb). 2017:7:65-79.

4. Philipsen HP, Reichart PA, Takata T, Ogawa I. Verruciform xan- thoma--biological profile of 282 oral lesions based on a literature survey with nine new cases from Japan. Oral Oncol. 2003;39:325-36. 5. Oliveira PT, Jaeger RG, Cabral LA, Carvalho YR, Costa AL, Jaeger MM. Verruciform xanthoma of the oral mucosa. Report of four cases and a review of the literature. Oral Oncol. 2001;37:326-31.

6. Neville BW, Weathers DR. Verruciform xanthoma. Oral Surg Oral Med Oral Pathol. 1980;49:429-34.

7. Ide F, Obara K, Yamada H, Mishima K, Saito I, Kusama K. Cellular basis of verruciform xanthoma: immunohistochemical and ultrastructural characterization. Oral Dis. 2008;14:150-7.

8. Mostafa KA, Takata T, Ogawa I, Ijuhin N, Nikai H. Verruciform xanthoma of the oral mucosa: a clinicopathological study with immunohistochemical findings relating to pathogenesis. Virchows Arch A Pathol Anat Histopathol. 1993;423:243-8.

9. Kakarantza-Angelopoulou E, Nicolatou O, Anagnostopoulou S. Verruciform xanthoma of the palate: case report with electron microscopy. J Oral Maxillofac Surg. 1991;49:409-12.

10. Miller AS, Elzay RP. Verruciform xanthoma of the gingiva: report of six cases. J Periodontol. 1973;44:103-5.

11. Zegarelli DJ, Aegarelli-Schmidt EC, Zegarelli EV. Verruciform xanthoma. A clinical, light microscopic, and electron microscopic study of two cases. Oral Surg Oral Med Oral Pathol. 1974;38:725-34. 12. Zegarelli DJ, Zegarelli-Schmidt EC, Zegarelli EV. Verruciform xanthoma. Further light and electron microscopic studies, with the addition of a third case. Oral Surg Oral Med Oral Pathol. 1975;40:246-56.

13. Cobb CM, Holt R, Denys FR. Ultrastructural features of the verruciform xanthoma. J Oral Pathol. 1976;5:42-51.

14. Graff SG, Burk JL Jr, McKean TW. Verruciform xanthoma. First case reported in a black person. Oral Surg Oral Med Oral Pathol. 1978;45:762-7.

15. Neville BW, Weathers DR. Verruciform xanthoma. Oral Surg Oral Med Oral Pathol. 1980;49:429-34.

16. Hume WJ, Smith CJ, Franklin CD. Verruciform xanthoma. Br J Oral Surg. 1980;18:157-61.

17. Nowparast B, Howell FV, Rick GM. Verruciform xanthoma. A clinicopathologic review and report of fifty-four cases. Oral Surg Oral Med Oral Pathol. 1981;51:619-25.

18. Sklavounou A, Laskaris G, Angelopoulos A. Verruciform xanthoma of the oral mucosa. Dermatologica. 1982;164:41-6.

19. Gehrig RD, Baughman RA, Collins JF. Verruciform xanthoma in a young male patient with a past history of pemphigus vulgaris. Oral Surg Oral Med Oral Pathol. 1983;55:58-61.

20. van der Waal I, Kerstens HC, Hens CJ. Verruciform xanthoma of the oral mucosa. J Oral Maxillofac Surg. 1985;43:623-6.

21. Correll RW, DeBoom GW. A well-circumscribed, asymptomatic, sessile nodule on the right side of the soft palate. J Am Dent Assoc. 1986;113:917-8.

22. Neville B. The verruciform xanthoma. A review and report of eight new cases. Am J Dermatopathol. 1986;8:247-53.

23. Rowden D, Lovas G, Shafer W, Sheikh K. Langerhans cells in verruciform xanthomas: an immunoperoxidase study of 10 oral cases. J Oral Pathol. 1986;15:48-53.

24. Blanco C, Miranda C, Fernández F, Val-Bernal JF, Garijo F, SaizBustillo R. Verruciform xanthoma of the lip: two lesions in a woman. Am J Dermatopathol. 1988;10:176-8.

25. Travis WD, Davis GE, Tsokos M, Lebovics R, Merrick HF, Miller SP et al. Multifocal verruciform xanthoma of the upper aerodigestive tract in a child with a systemic lipid storage disease. Am J Surg Pathol. 1989;13:309-16.

26. Drummond JF, White DK, Damm DD, Cramer JR. Verruciform xanthoma within carcinoma in situ. J Oral Maxillofac Surg. 1989;47:398-400

27. Takehana S, Kameyama Y, Fukaya M, Kawai T. Verruciform xanthoma of the gingiva: report of three cases. J Oral Maxillofac Surg. 1989;47:1079-81.

28. Toida M, Koizumi H. Verruciform xanthoma involving the lip: a case report. J Oral Maxillofac Surg. 1993;51:432-4.

29. Allen CM, Kapoor N. Verruciform xanthoma in a bone marrow 
transplant recipient. Oral Surg Oral Med Oral Pathol. 1993;75:591-4. 30. Neville BW, Coleman PJ, Richardson MS. Verruciform xanthoma associated with an intraoral warty dyskeratoma. Oral Surg Oral Med Oral Pathol Oral Radiol Endod. 1996;81:3-4.

31. Huang JS, Tseng CC, Jin YT, Huang CC, Wong TY, Chen HA et al. Verruciform xanthoma. Case report and literature review. J Periodontol. 1996;67:162-5.

32. Miyamoto Y, Nagayama M, Hayashi Y. Verruciform xanthoma occurring within oral lichen planus. J Oral Pathol Med. 1996;25:188-91.

33. Iamaroon A, Vickers RA. Characterization of verruciform xanthoma by in situ hybridization and immunohistochemistry. J Oral Pathol Med. 1996;25:395-400.

34. Shin HI, Choi KS, Nagatsuka H, Murata M, Nagai N. Verruciform xanthoma of the oral mucosa: an immunohistochemical and ultrastructural study of two cases. Oral Oncol. 1997;33:279-83.

35. Polonowita AD, Firth NA, Rich AM. Verruciform xanthoma and concomitant lichen planus of the oral mucosa. A report of three cases. Int J Oral Maxillofac Surg. 1999;28:62-6.

36. Shibata M, Kodani I, Tanio K, Yamamoto T, Ueta E, Osaki T, et al. Clinico-immunohistochemical Study of Oral Verruciform Xanthomas. Asian Journal of Oral and Maxillofacial Surgery. 2005;17:95-99.

37. Poulopoulos AK, Epivatianos A, Zaraboukas T, Antoniades D. Verruciform xanthoma coexisting with oral discoid lupus erythematosus. Br J Oral Maxillofac Surg. 2007;45:159-60.

38. Hu JA, Li Y, Li S. Verruciform xanthoma of the oral cavity: clinicopathological study relating to pathogenesis. Report of three cases. APMIS. 2005;113:629-34.

39. Pradhan S. Verruciform xanthoma of the oral mucosa. JNMA J Nepal Med Assoc. 2006;45:207-11.

40. Rawal SY, Kalmar JR, Tatakis DN. Verruciform xanthoma: immunohistochemical characterization of xanthoma cell phenotypes. $\mathrm{J}$ Periodontol. 2007:78:504-9.

41. Yu CH, Tsai TC, Wang JT, Liu BY, Wang YP, Sun A, et al. Oral verruciform xanthoma: a clinicopathologic study of 15 cases. J Formos Med Assoc. 2007;106:141-7.

42. Sah K, Kale AD, Hallikerimath S. Verruciform xanthoma: Report of two cases and review on pathogenesis. Journal of Oral and Maxillofacial Pathology. 2008;12:41-44.

43. Mete O, Kurklu E, Bilgic B, Beka H, Unur M. Flat-type verruciform xanthoma of the tongue and its differential diagnosis. Dermatol Online J. 2009;15:5.

44. Hatakeyama M, Alonso JM, Guilhermino M, Brandão AA, Cavalcante ASR. Verruciform xanthoma located in anterior gingiva. $\mathrm{J}$ Clin Exp Dent. 2010;2:e82-4.

45. Wesley R, Weaver R, Ojha J. Oral pathology quiz \#23. Verruciform xanthoma. J Mich Dent Assoc. 2010;92:34, 36-7.

46. Shahrabi Farahani S, Treister NS, Khan Z, Woo SB. Oral verruciform xanthoma associated with chronic graft-versus-host disease: a report of five cases and a review of the literature. Head Neck Pathol. 2011;5:193-8

47. Anbinder AL, Quirino MR, Brandão AA. Verruciform xanthoma and neurofibromatosis: a case report. Br J Oral Maxillofac Surg. 2011;49:e6-7.

48. Stoopler ET, Desai B. A tongue mass in a patient with oral lichen planus. J Can Dent Assoc. 2012;78:c60.

49. Teixeira V, Reis JP, Tellechea Ó, Vieira R, Figueiredo A. Verruciform xanthoma: report of two cases. Dermatol Online J. 2012;18:10 50. Bhalerao S, Bhat P, Chhabra R, Tamgadge A. Verruciform xanthoma of buccal mucosa: A case report with review of literature. Contemp Clin Dent. 2012;3:S257-9.

51. Raphael V, Das H, Sarma R, Shunyu B. Oral verruciform xanthoma: a case report. International Journal of Oral and Maxillofacial Pathology. 2012;3:65-67.

52. Joshi R, Ovhal A. Verruciform xanthoma: report of five cases. Indian J Dermatol. 2012:57:479-82.

53. Maldonado-Cid P, Noguera-Morel L, Beato-Merino MJ, de Lucas-Laguna R. Verruciform xanthoma associated with reactivation of Epstein-Barr virus. Actas Dermosifiliogr. 2013;104:445-6.
54. Dorankula SP, Ramani P, Premkumar P, Anuja, Sherlyn HJ. Verruciform xanthoma of the oral cavity - a case report. J Clin Diagn Res. 2013;7:1799-801.

55. Qi Y, Sun Q, Yang P, Song A. A case of multiple verruciform xanthoma in gingiva. Br J Oral Maxillofac Surg. 2014;52:e1-3.

56. Shetty A, Nakhaei K, Lakkashetty Y, Mohseni M, Mohebatzadeh I. Oral verruciform xanthoma: a case report and literature review. Case Rep Dent. 2013; doi:10.1186/s13104-017-2952-7.

57. Ryu DJ, Lee SH, Yuk JI, Kim HJ, Huh JK, Park KH. Verruciform xanthoma of the palatal gingiva: a report of two cases. J Korean Assoc Oral Maxillofac Surg. 2013;39:292-6.

58. Utsunomiya T, Matsumoto T, Morikawa M, Suemitsu M, Tanaka H, Ota Y, et al. Histopathological, Immunohistochemical and Exfoliative Cytological Studies of Oral Verruciform Xanthoma. Open Journal of Stomatology. 2014;4:435 - 440.

59. Aggarwal S, Aggarwal A, Gill S, Bakshi Y, Singh HP. Verruciform xanthoma of oral cavity- a case report. J Clin Diagn Res. 2014;8:11-2.

60. Archana M, Bahirwani S, Raja JV. A verruciform xanthoma of the lower lip and review of the differential diagnosis. Oral Health Dent Manag. 2014;13:712-6.

61. El-Kaissi AMN. Verruciform Xanthoma in Severe PhenytoinInduced Gingival Overgrowth: A Case Report. Clinical Advances in Periodontics. 2014;4:99-104.

62. Marques YM, de Andrade CR, Machado de Sousa SC, Navarro CM. Oral verruciform xanthoma: a case report and literature review. Case Rep Pathol. 2018:2018;1615086.

63. Gibson TM, Martin BD. Clinicopathologic conference case 1: incidental finding on left posterior tongue. Oral Surg Oral Med Oral Pathol Oral Radiol. 2014;118:e84-6.

64. Harris L, Staines K, Pring M. Oral verruciform xanthoma. BMJ Case Rep. 2015;2015.pii: bcr2014209216.

65. de Andrade BA, Agostini M, Pires FR, Rumayor A, Carlos R, de Almeida OP, et al. Oral verruciform xanthoma: a clinicopathologic and immunohistochemical study of 20 cases. J Cutan Pathol. 2015;42:489-95

66. Xue R, Su W, Pei X, Huang L, Elbendary A, Chen Z. Multiple verruciform xanthomas following bone marrow transplant. Indian J Dermatol Venereol Leprol. 2016;82:208-9.

67. Pereira T, Shetty S, Dodal S, Tamgadge A. Verruciform xanthoma of the lip: A rarity. Indian Dermatol Online J. 2016;7:180-2.

68. Kimura M, Ohto H, Shibata A, Enomoto A, Umemura M. Clinicopathological and Immunohistochemical Characteristics of Verruciform Xanthoma of the Lower Gingiva: A Case Report. J Clin Diagn Res. 2016;10:5-6

69. Garcia AS, Pagin O, da Silva Santos PS, Oliveira DT. Verruciform xanthoma in the hard palate: a case report and literature review. J Korean Assoc Oral Maxillofac Surg. 2016;42:383-387.

70. Hiraishi Y, Tojyo I, Kiga N, Tanimoto K, Fujita S. A Case of Verruciform Xanthoma Arising in the Tongue. J Clin Diagn Res. 2016:10:7-8

71. Monteiro MCDLJ, Furuse C, Cê LC, Santana AF, Araújo VCD. Verruciform xanthoma: case report. RGO-Revista Gaúcha de Odontologia. $2016 ; 64: 79-82$

72. Huang YF, Hsu JD, Yang HW. Multiple oral verruciform xanthoma treated with cryotherapy. Journal of Dental Sciences. 2017:12:105-106.

73. Byakodi S, Kumar B, Patil S, Shinde S. Verruciform xanthoma of the tongue. Natl J Maxillofac Surg. 2017;8:78-80.

74. Sopena J, Gamo R, Iglesias L, Rodriguez-Peralto JL. Disseminated verruciform xanthoma. Br J Dermatol. 2004;151:717-9.

75. Jones AV, Franklin CD. An analysis of oral and maxillofacial pathology found in adults over a 30-year period. J Oral Pathol Med. 2006:35:392-401.

76. Mehra S, Li L, Fan CY, Smoller B, Morgan M, Somach S. A novel somatic mutation of the 3beta-hydroxysteroid dehydrogenase gene in sporadic cutaneous verruciform xanthoma. Arch Dermatol. 2005;141:1263-7. 
Acknowledgements

None.

Conflict of Interest

All authors declare that they have no conflict of interest. 